Valóságos könyvtár - könyvtári valóság. Könyvtár- és információtudományi tanulmányok 2016. Szerk. Kiszl Péter, Boda Gáborné Köntös Nelli.

Budapest, ELTE BTK Könyvtár- és Információtudományi Intézet. 2017. 79-88.

\title{
AZ ERDÉLYI MAGYAR NYELVÜ KÖNYVTÁROSKÉPZÉS TÖRTÉNETE
}

\author{
GURKA-BALLA ILONA
}

Babes-Bolyai Tudományegyetem, egyetemi tanársegéd

\begin{abstract}
ABSZTRAKT
A felsőfokú könyvtárosképzés Erdélyben is az elmúlt évtized könyvtár-szakmai és felsőoktatási változásaihoz igazodott. A kolozsvári egyetemi fokú magyar nyelvű képzés könyvtár-stratégiai tényezővé, a könyvtáros-pálya kulcskérdésévé vált, sőt örvendetesen erősödött a tanszék és a hallgatók leendő munkáltatói közötti kapcsolat. A szaksajtó és a média is előnyösen járult hozzá a fejlődéshez. Az érvényben levő kormányrendelet értelmében az egyetemi szak elnevezése „informatikus könyvtáros”, „információs menedzser” lett a „könyvtáros” szakképesítés mellett, ezzel is jelezve a nemzetközi trendekhez való igazodást. A kolozsvári Babes-Bolyai Tudományegyetemen már a kezdetektől hagyománya van a könyvtárosképzésnek. Már Gyalui Farkasék is nagy hangsúlyt fektettek e szak egyetemi szintû képzésére. A II. világháború után sajnos csak román nyelvű volt a szakmai képesítés, az is csak Bukarestben. A 90-es években azonban újra lehetővé vált, hogy magyar nyelven is elvégezhessék a diákok a könyvtárszakot. Először főiskolai szinten (3 éves), majd egyetemi szinten (4 éves képzés után) kaptak a diákjaink történelem- és könyvtárszakos diplomát. A bolognai rendszerben csak a 3 éves könyvtárszakos alapképzés maradt meg, de reméljük, hogy a korábbi hazai könyvtárosképzés egyik jelentős vívmányát, a kétszakosságot a bolognai folyamat egyszakos struktúrájába is át lehet majd menteni; ehhez a leendő munkahelyeknek, a könyvtáraknak és más információ-szolgáltató helyeknek, az iskoláknak is érdekük füződik. Az egyetemi képzést mindvégig jelentősen támogatta a helyi szinten, a nagyobb múvelődési központokban folyó szakmai továbbképzések és tanfolyamok megszervezése. Közös célunk lépést tartani a szakmabeli változásokkal és az állandóan megújuló információs társadalom kihívásaival.
\end{abstract}

A felsőfokú könyvtárosképzés Erdélyben is az elmúlt évtized könyvtár-szakmai és felsőoktatási változásaihoz igazodott. A kolozsvári egyetemi fokú magyar nyelvű képzés könyvtár-stratégiai tényezővé, a könyvtáros pálya kulcskérdésévé vált, sőt örvendetesen erősödött a tanszék és a hallgatók leendő munkáltatói közötti kapcsolat is. A szaksajtó és a média is előnyösen járult hozzá a fejlődéshez.

Az érvényben levő kormányrendelet ${ }^{1}$ értelmében az egyetemi szak elnevezése ,informatikus könyvtáros”, „információs menedzser” lett a „könyvtáros” szakképesítés mellett, ezzel is jelezve a nemzetközi trendekhez való igazodást. A szakról bővebben a kolozsvári Babes-Bolyai Tudományegyetem (BBTE) honlapján olvashatnak. ${ }^{2}$ Az egyetem alapításától kezdve (1872) az erdélyi magyar nyelvű nevelés sarokköve, alappillére. 1940ben tanévnyitó ünnepi beszédében Hóman Bálint, az akkori vallás- és közoktatásügyi miniszter így összegezte e tudományegyetem művelődéspolitikai jelentőségét: „Ennek 
az ôsi erdélyi, avagy magyar szellemnek legjellemzőbb sajátosságai közé tartozik a nemzetbomlasztó ellentétek, a felekezeti, a nemzetiségi, a hivatásköri, a nemzedékközi és osztályközi viszályok enyhítésére és megszüntetésére irányuló tudatos törekvés s a művelődés után való hatalmas vágyakozás. [...] Erdély népének a művelődés után való vágya jut kifejezésre íróinak, mûvészeinek, tudósainak, de éppen így falusi népének, városi iparosainak, tanítóinak, papjainak, főurainak nemzeti művelődésünket gazdag értékekkel gyarapító munkásságában. [...] A művelődés vágya hívta életre hosszas elôkészítés után [...] a Ferenc József Tudományegyetemet is."3

Sajátossága az egyetemi könyvtárhoz való szoros kötődése, amelyet az egyetemmel egyidóben létesítettek. E rangos intézmény nemcsak teret nyújt a képzéshez, hanem a szakmai felkészülésre, a gyakorlatra is lehetőséget teremt a diákok számára. Élettér a könyvtár - tanulásra, munkára, kutatásra és kommunikációra - diákok, tanárok és mindenki számára. Hagyományra építkező jelenként nyilik meg előttünk ez a „közösségi tér”. A hagyományos cédulakatalógusok mellett számítógépek sokasága biztosítja az online katalógushoz való hozzáférhetést. Sőt, a multimédia teremben a könyvtár által előfizetett és a helyi adatbázisok ${ }^{4}$ is lekérdezhetők, s az ingyenes internethasználat itt és az olvasótermekben is biztosított. Az olvasói igényekhez igazodva több termet szabadpolcos olvasótermekké alakítottak át. Az egyetemi könyvtár jeles könyvtárosai, igazgatói közül elsőként említjük Szabó Károlyt (1824-1890), az első „,könyvtárőr’-t, aki először az Erdélyi Múzeum-Egyesület könyvtárában, majd 1872-től az egyetemi könyvtárban töltötte be ezt a tisztséget. Ferenczi Zoltán (1857-1927) volt az Egyetemi Könyvtár következő igazgatója 1891 és 1899 között, ôt Erdélyi Pál (1864-1936) követte 1900-tól 1919-ig. E minőségében ő szervezte meg a könyvtár új épületbe költöztetését, berendezését és múködését. Külön kiemelem jeles könyvtárosaink közül Gyalui Farkas (1866-1952) nevét, aki 1891-től a kolozsvári egyetemi könyvtárban dolgozott és 1901-től 1919-ig egyetemi magántanárként a könyvtár tanszék vezetője. E minőségében elsőként dolgozta ki a könytárosképzés intézményes rendszerét. Pogányné Rózsa Gabriella a Könyvtári Figyelóben megjelent tanulmányában tudományos alapossággal elemzi Gyalui Farkas e tevékenységét Sebestyén Györgyre hivatkozva: „Elévülhetetlen érdemei vannak Gyalui Farkasnak abban, hogy a könyvtári ismeretek Magyarországon úgyszintén egyetemi diszciplínává - ha nem is 'igazi' tanszékké, de egyetemen oktatható és oktatandó elismert tudománnyá - emelkedtek". ${ }^{2}$

A korabeli külföldi és magyar szaksajtó sokat foglalkozott e kérdéssel, a Múzeumok és Könyvtárak Országos Főfelügyelősége 1898-tól kezdődően rendszeresen tartott „Könyvtárnoki tanfolyam”-okat.

A felsőoktatás bevonása a szakképzésbe azonban minden kétséget kizáróan Gyalui Farkas kezdeményezésére történt meg. ${ }^{6}$

A Magyar Könyuszemle Gyalui Farkas kinevezéséről így tudósított 1901-ben: „A vallásés közoktatásügyi m. kir. miniszter úr ő méltósága dr. Gyalui Farkas [1898. január 6-a óta] kolozsvári egyetemi könyvtárőrnek a kolozsvári egyetemen a könyvtártudományokból történt magántanári képesítését jóváhagyta s nevezettet ezen állásában megerősítette. [...] 
Különös jelentőséget ad egyébként ezen eseménynek az a körülmény, hogy a bibliografia először foglal helyet általa magyar főiskolán a tudományos kollégiumok sorában. S a kolozsvári egyetem kétség nélkül büszke lehet arra, hogy ebben a tekintetben megelőzte az ország első egyetemét."7

Gyalui Farkas szavait idézve: „Ami az egyetemi katedrát illeti, ha három egyetem volna, s három katedra volna, az is kevés volna. Mert nem könyvtárosokat [...], de ügybarátokat, bibliofileket, könyvszerető s ismerő embereket képezni kell, s ha ilyeneket ezrével képezünk ki: annál jobb." ${ }^{8}$ Gyalui legfontosabb könyvtárelméleti és könyvtártani közleményei: A nyomdatermékek köteles példányai (Kolozsvár : Minerva, 1897); Külföldi közkönyvtárakról : tanulmány Németország, Svájc, Franciaország, Anglia, Hollandia, Belgium és Ausztria nevezetesebb közkönyvtárairól (Kolozsvár : Ajtai, 1900); A könyvtári tudományok célja és feladata Magyarországon (Kolozsvár : Ellenzék Ny., 1903); Legkedvesebb könyveim (Budapest : Singer és Wolfner, 1902); A magyar könyvtárak jövőjéről (Budapest : Franklin, 1904).

A könyvtártudomány területei Gyalui Farkas értelmezésében: a könyvtárak „tudományos és közmívelődési intézmények", s mint könyvtári rendszernek a feladatai közé tartozik: az állandó és rendszeres megőrzés, a legteljesebb nyilvánosság, a szolgáltatás 9 , a tudás minél demokratikusabbá tétele ${ }^{10}[. .$.$] Nézetei szerint a könyvtártudomány több,$ egymástól jól elkülöníthető részre tagolódik: ${ }^{11}$

1. terület: Az intézmények jelenére és jövőjére vonatkozik a könyvtártan. A könyvtártan másik tartalmi egysége az állomány kezelése: elhelyezése, védelme, rendezése és feldolgozása, melynek lehetőség szerint nemzetközileg egységes elvek, szabályok szerint kell történnie.

2. terület: Történeti megközelítésben a könyvnyomtatás históriája, a könyvtörténet és a bibliográfia (összességében a bibliológiai irányzat), ezek a kutatások teszik lehetôvé a múlt patriotikum irodalmának a regisztrálását, ezáltal hozzáférhetővé válását, szolgáltathatóságát is; de éppily elengedhetetlen a könyvtárak, könyvtári intézmények történetének feldolgozása és megismertetése. ${ }^{12}$

3. terület - külön területként nem említette, de szintén e diszciplína részének tekintette az olvasás vizsgálatát: a művelődés- és olvasásszociológiát - a mai terminológiával élve. „Legkedvesebb könyveim”"13 című összeállításában híres magyar írók, tudósok vallanak legjelentősebb olvasmányélményeikról. ${ }^{14}$

Hivatalos kinevezése ${ }^{15}$ után kurzusait 1902 februárjában kezdte meg. Előadásaiban az egyetemi szintű könyvtárosképzés megszervezésének egyik első szószólójaként hivatkozott Rullmannra. ${ }^{16}$ A könyvtárosképzés súlypontjairól szólva előfeltételnek tekintette a hivatás gyakorlásához a megfelelő nyelvtudást (latin, görög, francia mellett héber, angol, olasz, spanyol). Ehhez kell társulnia a segédtudományok (történet- és irodalomtudomány, tudományfelosztások) ismeretének, illetve ezekre az alapokra épülnek a „szaktárgyak”: a kézirattan, nyomdászattörténet, könyvkereskedelem története, múvészeti ismeretek (pl. 
illusztrációs technikák), a könyvtártudomány tudománytörténete, a könyvtárismeret, a könyvtár- és a levéltártan, illetve a katalogizálási gyakorlatok. Az egyetem tanrendjei ${ }^{17}$ alapján ismeretes, hogy Gyalui Farkas - néhány félév kivételével - heti két órában tartott ingyenes előadásokat ${ }^{18}$ - mindegyik tantárgyat általában két szemeszteren keresztül oktatva a hallgatóknak.

A meghirdetett leckék (tanegységek) címei nagyjából megegyeznek a Grafikai Szemleben közöltekkel: 'A könyvtárak története és fejlődése' elnevezésű elöadások; 'Az elméleti és gyakorlati könyvtártan'-t - a korabeli, még kissé kialakulatlan terminológiai rendszer miatt - 'bibliotheconomia' megjelöléssel illette; a 'Bibliográfia' című tantárgy hangsúlyozottan a magyarországi könyvészetek történetével, fejlődésével foglalkozott; az 1912/1913-as tanévben 'Az időszaki sajtó története és bibliographiája' címmel új kurzust indított.

Gyalui a saját életére visszatekintve így foglalta össze életpályáját: „[Kolozsvárott] maradtam könyvtárosnak [...] testemmel megvédeni azt a könyvtárt és levéltárt, melyben Erdély múltjának annyi kincse van. [...] egyetemre vittem szakomat tudománynak, mert magam elé tűzött legfőbb feladatom volt, legyen az országban minden faluban és városban nyilvános könyvtár. Ezen dolgoztam, agitáltam, több mint 1000 hallgatómnak 18 éven át ezt tanítottam s erre képeztem ki ôket. A szépirodalom, melyre Petelei szánt, első szerelmemnek megmaradt, de amint megszólalt bennem, önként egy-egy bájos téma, feljegyeztem és félretettem. Író és poéta volt elég, de, külföldön megtanultam, hogy könyvtárépítő és könyvtárakért agitáló nincs. Végeztem ezt. Itt maradtam 1918 után is." ${ }^{19}$

1919 után azonban az ígéretes kezdet ellenére a magyar nyelvű erdélyi könyvtárosképzés szinte teljesen megszűnt, s 1945 után már csak román nyelvű volt, az is csak Bukarestben. Majd 1989 után, a 90-es években újra lehetővé vált, hogy magyar nyelven is elvégezhessék a diákok a könyvtár szakot. Képzésük helyszíne az egyetemi könyvtár volt, és ma is az.

1990 után a kolozsvári egyetemi fokú magyar nyelvű képzés könyvtárstratégiai tényezővé, a könyvtáros pálya kulcskérdésévé vált, sőt, a könyvtár szakot felölelő Történelem és Filozófia Kar és a hallgatók leendő munkáltatói közötti kapcsolat is jelentősen erősödött. Az egyetemi könyvtár nemcsak a tanulmányok színhelye, hanem munkahely is a továbbiakban - végzős diákjaink számára.

Főiskolai szintű (3 éves) volt a képzés 1995 és 1999 között. A kolozsvári BabesBolyai Tudományegyetem Történelem és Filozófia Karán román, magyar és német nyelven sajátíthatták el a hallgatók a történelem-könyvtártan szakot. A magyar tagozaton 55-en végeztek.

Egyetemi szintû négyéves képzés 1998 és 2008 között volt - 60 egyetemi hallgató végezte el magyar nyelven a történelem-könyvtárszakot - kettős diplomát kapva: történelemtanári és könyvtáros képesítést.

A bolognai rendszerben 2005-től kezdődően csak a 3 éves könyvtárszakos alapképzés maradt meg, amely időközben ötvöződött az információtudományi szakképesítéssel. 2005-tôl napjainkig 29-en végezték el ezt a szakot magyar nyelven. 
Így valósult meg és építkezik tovább ma is a Gyalui Farkasék által kezdeményezett alapokra a könyvtárosképző szakirány a Babes-Bolyai Tudományegyetemen. Hadd tegyük hozzá azt is, hogy Romániában egyedül Kolozsváron volt és van egyetemi szintű magyar nyelvű könyvtáros szakmai képzés. 1995 után napjainkig könyvtárszakon tanító tanáraink: Sipos Gábor, Újvári Mária Magdolna, Zaharia Etelka, Sebe Katalin, Poráczky Rozália, Olimpia Curta, Doru Radosav, Ioan Aurel Pop, Lucia Hosu, Nagy Róbert, Rüsz-Fogarasi Enikő, Pál Judith, Lupescu Makó Mária, Lönhárt Tamás, Tóth Szilárd, Vekov Károly, Ungvári-Zrinyi Imre, Salat Levente, Vincze Orsolya, Zörgő Noémi, Kiss Dénes, Kádár Magor, Benedek József, jómagam és még sokan mások.

A Könyvtár- és információtudomány szak ${ }^{20}$ jelenleg érvényes tanrendje $e^{21}$ lényegében megegyezik az eddigiekkel, újdonság azonban az információtudomány és a kommunikációelmélet tantárgyainak a bevezetése és az informatikai alapismeretek elsajátítása.

A továbbiakban remélhetőleg a korábbi hazai könyvtárosképzés egyik jelentős vívmányát, a kétszakosságot a bolognai folyamat egyszakos struktúrájába is át lehet majd menteni. Ehhez a leendő munkahelyeknek, a könyvtáraknak és más információ-szolgáltató helyeknek, illetve az iskoláknak is érdeke füződik.

Az utolsó húsz évben Erdélyben 89-en végezték el magyar nyelven egyetemi szinten a könyvtárszakot a kolozsvári BBTE-n, és 55-en föiskolai szinten. Eddig összesen 144-en szereztek Kolozsváron diplomát könyvtárszakból (először történelemmel párosítva, majd az új trendhez igazodva az információtudománnyal ötvöződve). Az ,informatikus könyvtáros” és „információs menedzser” szakirányok társultak tehát a „könyvtáros" szakképesítéshez, ezzel is jelezve a nemzetközi trendekhez való igazodást. Új trend ez a kolozsvári könyvtárosképzésben: könyvtár- és információtudomány együtt.

A szakmai továbbképzéseket és a tanfolyamokat is felvállalta az egyetem. A Babes-Bolyai Tudományegyetem szervezésében magyar nyelven is tartottak az iskolai könyvtárosok kérésére továbbképző tanfolyamokat. Elmondhatjuk, hogy az egyetemi alapképzést mindvégig jelentôsen támogatta a helyi szinten, a nagyobb múvelődési központokban folyó szakmai továbbképzés és tanfolyamok megszervezése is. A szaksajtó és a média is előnyösen járul hozzá a szakmai fejlődéshez, az előrelépéshez. A továbbképzésekről, a szakmai találkozókról, a kerekasztal-beszélgetésekről stb., minden fontosabb eseményrôl a médián keresztül is tájékozódunk.

Szakmai továbbképzéseket a résztvevők igényei alapján helyi szinten is szerveznek. A Hargita megyei könyvtárosok blogján például rendszeres tájékoztatást lehet kapni a helyi továbbképző és szakmai tevékenységekről. ${ }^{22}$

Tanáraink és diákjaink rendszeresen részt vesznek a tudományos konferenciákon. Az egyik legrangosabb szakmai rendezvényen, a Magyar Könyvtárosok IV. Világtalálkozóján 1996-ban Zaharia Etelka tartott előadást Könyvtárosképzés Erdélyben címmel, ${ }^{23}$ aki az 1995-1996-os tanévben a Tudományos tájékoztásról és a bibliográfiák rendszeréröl tartott előadásokat egyetemi hallgatóinknak. Az V. Világtalálkozón, 2000-ben az egyetemi könyvtár aligazgatónője, Poráczky Rozália tartotta meg előadását A kolozsvári Lucian Blaga Egyetemi Könyvtár 1990 és 2000 között címmel. ${ }^{24}$ 2004-ben a VI. Világtalálkozón jómagam 
beszéltem Helytörténeti kutatások megkönnyitése az interneten. Mübelytitkok adatbázisok összeállitásáról címmel. ${ }^{25}$ 2013-ban pedig a VII. Világtalálkozón volt diákjaink és az egyetemi könyvtár digitális laboratóriumában dolgozó kollégáink, Brem Ágnes és Bodnár Róbert adott elő (A Kolozsvári Központi Egyetemi Könyvtár digitalizálási tevékenysége). ${ }^{26}$

Hírt kaphattunk és kapunk a médiában több rangos eseményről, többek között A Romániai Magyar Könyvtárosok Egyesületének (RMKE) 2015. október 14-15-én „Könyvtárak a minőségért" témakörben tartott konferenciájáról, ahol diákjaink biblioterápiai és olvasásfejlesztési kutatásairól tartottam előadást. Ugyancsak ezen a konferencián számolt be élményeirôl színes és gazdag képanyagban Kiss László, a sepsiszentgyörgyi Mikes Kelemen Elméleti Líceum könyvtárosa, aki 2015 júliusában a Bolyai Nyári Akadémián is tartott beszámolót a jelentős vállalkozásáról: a Fekete-tengertől a Fehér-tengerig (Hágáig) tartó bicikliútjáról, valamint az iskolai könyvtárosok nemzetközi konferenciáján való részvételéről. Utazását a Facebookon is nyomon követhettük. Mindenhol lelkesen fogadták és több találkozót szerveztek vele.

Hazatérve lelkesen megosztotta kollégáival és az érdeklődőkkel élményeit. A konferencián a hazai iskolai könyvtárak mai helyzetéről tájékoztatta a résztvevőket.

Szakmabeli hírforrásaink még:

1. A ReMeK-e-hírlevél, a Romániai Magyar Könyvtárosok Egyesületének (RMKE) elektronikus könyvtári hírlapjának a rovatai. ${ }^{27}$

2. A kolozsvári BBTE Könyvtár- és információtudomány szak magyar nyelvű honlapja ${ }^{28}$ és Facebook-oldala. ${ }^{29}$

Egyetemünk magyar nyelvű honlapján, Facebook-oldalunkon minden jelentős szakmai találkozóról, diákjaink életének néhány jeles eseményéről és minden közérdekű információról hírt kapunk.

Hallgatóink szakdolgozataikban kifejtett kutatásaik során jelentősen hozzájárultak a könyvtáros és információmenedzser szakma elismertetéséhez: helytörténeti bibliográfiákat, ${ }^{30}$ sajtóbibliográfiákat készítettek, ${ }^{31}$ olvasásszociológiai felméréseket végeztek, régi könyvek digitalizálási folyamatát mutatták be, jelenleg az e-book iskolai könyvtári használatáról is végeznek kutatásokat, valamint biblioterápiai tevékenységekre is vállalkoznak, természetesen megfelelő szakmai háttérrel, elsősorban az olvasásfejlesztésre szúkítve.

ERASMUS, CEPUS-ösztöndíjjal a szegedi, a pécsi, és hamarosan a budapesti tudományegyetemeken is betekintést nyerhetnek a külhoni diákéletbe, részt vehetnek az ottani kutatásokban, és visszatérve Kolozsvárra, idehaza tudják értékesíteni és továbbfejleszteni tanulmányaikat.

Egyelőre csak az alapképzésben van arra lehetőségünk, hogy diákjaink magyar nyelven végezhessék tanulmányaikat.

Román nyelven is tartanak évente szakmai továbbképző tanfolyamokat az egyetemi könyvtárban, az egyetem és könyvtárunk honlapján értesülünk e képzések időpontjáról és helyszínéről. Román nyelvű felsőbb fokú mesteri (a svájci ETH Egyetemmel együttmúködve) és doktori képzés is van könyvtár- és információtudomány szakirányokban. 
Könyvtár- és információtudomány szakos diplomásaink magyar nyelven folytathatják magasabb szintű, magiszteri tanulmányaikat az örökségvédelem keretében, doktori tanulmányaikat pedig a Történelem és Filozófia Kar professzorainak irányításával.

A kolozsvári könyvtár szakos egyetemi hallgatóinknak nemcsak a tanulmányaik, szakmai gyakorlatuk színhelye, élettere, közösségi tere az egyetemi könyvtár, hanem munkahely is lett sokuk számára.

A könyvtár jelenlegi aligazgatónője, Poráczky Rozália 2000-ben, a Könyvtárosok Világtalálkozóján tartott már említett előadásában ezt külön hangsúlyozta: „Az elmúlt tíz évben jelentősen emelkedett a hálózatban ${ }^{32}$ dolgozó könyvtárosok száma. Míg 1990ben 148, addig 2000-ben 174 fő a szakmai munkatárs. Közülük jelenleg 23 a magyar könyvtáros (1997-ben számuk 16 volt)."’33

Hivatástudatuk által ösztönözve alkalmazzák végzőseink a mindennapi életben egyetemi tanulmányaik során elsajátított tudásukat. Bizonyságot tesznek arról, amit Kristóf György, a kolozsvári Babes-Bolyai Tudományegyetem Bölcsészet-, Nyelv- és Történettudományi Karának dékánja mondott 1944-ben: „[...] az egyetem mindenek előtt tudományt művelő, tudományos intézet [...] Nem tudásra nevel, hanem tudományra; nem kész ismereteket, tanokat, dogmákat közöl, hanem az ismeretlenre, a homályosságokra, a sötét foltokra akar világot vetni. [...] az egyetem léte és lényege a probléma megoldása, a kétségek helyén rend és bizonyosság teremtése. Közvetlenül vagy közvetve ezt végezni a hivatása és rendeltetése az egyetem minden egyes dologi vagy személyi alkotó elemének: a laboratoriumoknak, szemináriumoknak, könyvtáraknak, a professzoroknak, a tudományos segédszemélyzetnek stb. egyaránt. És ezt a tudományos munkát megismerni, megérteni, átélni, hogy aztán egy egész életen át [...] magunk is cselekvő, alkotó, a tudományt továbbfejlesztő tagjai lehessünk a szellem köztársaságának [...]”34

Ez a szellem hatja át a kolozsvári egyetemi könyvtár tevékenységét már több mint egy évszázada, ennek ösztönzésére ma is nyitottak minden újra az itt dolgozó „könyvtárőrök”, mai nyelven mondva „információmenedzserek”, és az ebben az élettérben tanuló, gyakorlatozó diákjaink is e hagyományok szellemében vállalják a jövő újabb és újabb kihívásait. Az itt dolgozókkal együtt cselekvő és alkotó részesei az egyetemi könyvtárban zajló munkafolyamatoknak.

1992-ben kezdte meg tevékenységét az informatika labor a könyvtárban, 1995től már a VUBIS programban dolgozva építették az online katalógust, 1999-től pedig az ALEPH integrált könyvtári rendszerben készítették a bibliográfiai rekordokat. Jelenleg a könyvtár teljes cédulakatalógusa digitalizálva van ${ }^{35}$. Emellett párhuzamosan végzik a retrospektív konverziót is az új könyvek feldolgozása mellett ${ }^{36}$. A hozzáférhetőség szempontjából elmondhatjuk, hogy a dokumentumszolgáltatás hagyományos és digitális formában, de teljesen integrált rendszerben történik. A Digitális Könyvtár négy fő részből áll: a Transilvanica gyűjteményből (mely tartalmazza a nemzeti kulturális örökségbe és a folyóiratokba tartozó megfontoltan kiválasztott kiadványokat); a kérésre digitalizált és a más intézményekkel való együttműködés során keletkezett dokumentumokból, valamint a saját kiadványokból. A Transilvanica gyűjteményt 2008-tól építik és 


\section{GURKA-BALLA ILONA}

az Erdélyre vonatkozó digitalizált dokumentumokat tartalmazza, jelenleg 115 kéziratot, 596 régi és ritka könyvet, 2116 ikonografikus dokumentumot és más dokumentumokat találhatunk ebben a Digitális Könyvtárban. 2012-tôl az EBSCO Discovery Services (EDS) keresőrendszert használják, amelynek segítéségével egy időben lehet az online katalógust használni és a könyvtár által hozzáférhetővé tett adatbázisokat lekérdezni. A Digitális Könyvtár anyagában a DSpace segítségével a teljes szövegben lehet keresni, és nagyon barátságos a kezelőfelület az olvasók számára. A könyvtárnak saját B-kategóriás folyóirata is van, a Philobiblon. ${ }^{37}$

E fentebb ismertetett szoros kapcsolat a BBTE hallgatói, tanárai és az egyetemi könyvtár között „élő és a jövőbe tekintő közösségi teret” hozott létre Kolozsváron. Apáczai Csere János diákjaiként mi is teli batyuval lépünk az Életbe, és töretlen hittel követjük azokat, akik tudással feltarisznyáznak és utat mutatnak a továbblépéshez, s amikor eljön az idő, mi is továbbadjuk majd mindazon kincseket, amelyeket örökül ránk hagytak az elődeink.

\section{Irodalom és jegyzetek}

1 A 2011-ben hozott 966-os számú kormányrendelet értelmében, amelyet megerősítettek a 707/2012, a 493/2013, 580/2014, 575/2015, 376/2016 rendeletek.

2 A kolozsvári Babes-Bolyai Tudományegyetem Könyvtár- és Információtudományi szakja. Forrás: http://kmti.hiphi.ubbcluj.ro/oktatas/alapkepzes/konyvtar_informaciotudomany_szak [2015. október 30.]

${ }^{3}$ Erdély magyar egyeteme: az erdélyi egyetemi gondolat és a M. Kir. Ferenc József Tudományegyetem története. BISZTRAY Gyula, SZABÓ T. Attila, TAMÁS Lajos szerk. Kolozsvár, Az Erdélyi Tudományos Intézet, 1941. 11. p.

${ }^{4}$ Mint például EBSCO, Springerlink, Emerald, ProQuest, JSTOR, Exford Journals, ScienceDirect, Arcanum stb.

${ }^{5}$ POGÁNYNÉ RÓZSA Gabriella: Habent fata sua libelli et bibliothecarii: Gyalui Farkas életútja és könyvtártani munkássága. = Könyvtári Figyelő, 50. évf. 4. sz. 2004. 763-793. p. Forrás: http://ki.oszk.hu/kf/2004/01/habent-fata-sua-libelli-et-bibliothecarii-gyalui-farkas-elet[-] utja-es-konyvtartani-munkassaga/\#posts [2015. október 30.]

${ }^{6}$ SEBESTYÉN György: Az egyetemi könyvtárosképzés ötven éve: az ELTE Könyvtártudományi Tanszékének rövid története. Budapest, ELTE Eötvös Kiadó, 2001. 33. p.

${ }^{7}$ A könyvtári tudományok a kolozsvári M. Kir. Ferencz-József Tudomány-Egyetemen. = Magyar Könyvszemle, (9. évf.) 4. sz. 1901. 417. p.

${ }_{8}^{8}$ Több forrásban is olvasható, hogy Gyalui egyetemi előadásainak összesen mintegy ezer hallgatója volt, konkrét adat magántanári múködésének kezdetéről, hogy egy-egy kurzusán 60-100 egyetemista vett részt. [GYALUI Farkas: Stockinger: A magyar könyvtárak jövőjéról (Ismertetés). = Zentralblatt für Bibliothekswesen, 1905. 586. p.]

${ }^{9}$ GYALUI Farkas: A könyvtári tudományok célja és feladata Magyarországon. Kolozsvár, Ellenzék Nyomda, 1903. 5. p.

${ }^{10}$ Gyalui Farkas levele Szabó Ervinhez. Kolozsvár, 1903. február 5. In: Szabó Ervin levelezése: 1893-1904. Budapest, Kossuth, 1977. 248. p. 
${ }^{11}$ GYALUI Farkas: A könyvtári tudományok célja és feladata Magyarországon. Kolozsvár, Ellenzék Nyomda, 1903. 12-19. p.

${ }^{12}$ GYALUI Farkas: A székely-udvarhelyi ev. ref. gimnázium könyvtára. = Magyar Könyvszemle, 19. évf. 4. sz. 1895. 332. p.

${ }^{13}$ GYALUI Farkas: Legkedvesebb könyveim. Budapest, Singer és Wolfner, 1902. 160 p.

${ }^{14}$ Gyalui munkájából is származó válogatás olvasható a Magyar Bibliofil Társaság 1991-es évkönyvében. Könyv és betúk: írók, költők vallomásai a könyvről. Budapest, Magyar Bibliofil Társaság, 1991. (A Magyar Bibliofil Társaság évkönyve) 5-32. p.

15 1901. október 10-én

16 RULLMANN, F. : Die Bibliothekseinrichtungs-kunde zum Theile einer gemeinsamen Organisation, die Bibliothekswissenschaft als solche einem besondern Universitätsstudiu in Deutschland unterworfen. Freiburg, Wagnes'sche Buchhandlung, 1874. 23-24. p.

${ }^{17}$ A kolozsvári „Ferencz-József” Magyar Királyi Tudomány-Egyetem almanachja és tanrendje. Kolozsvár, Ajtai, 1901-1918.

18 „A fizetésnélküli rendkívüli és magántanárok a rendes leckepénzért vagy ennél magasabbért tarthatják előadásaikat. A 45. \-ban jelzett [kötelező illetve megengedett] ingyenes előadások tartása is szabadságukban áll." - olvasható A kolozsvári Magyar Királyi Ferencz-József-TudományEgyetem tanulmányi, fegyelmi és leczkepénz szabályzatának 55. paragrafusában. A kolozsvári Magyar Királyi Ferencz-József-Tudomány-Egyetem tanulmányi, fegyelmi és leczkepénz szabályzata. Kolozsvár, Ajtai, 1893. 19. p.

${ }^{19}$ GYALUI Farkas levele Jakab Ödönhöz. Kolozsvár, 1930. március 25. OSZK Kézirattára, Levelestár.

20 A kolozsvári Babes-Bolyai Tudományegyetem Könyvtár- és információtudományi szakja. Forrás: http://kmti.hiphi.ubbcluj.ro/felveteli/alapkepzes_nappali [2016. június 13.]

21 A kolozsvári Babes-Bolyai Tudományegyetem Könyvtár- és információtudományi szak tanrendje. [Szerzői fordítás.] Forrás: http://hiphi.ubbcluj.ro/studii/licenta/biblioteconomie. html [2016. június 13.]

22 A Hargita megyei magyar iskolakönyvtárosok blogján található továbbképzések, szakmai tevékenységek. Forrás: http://hriskkonyvtaros.blogspot.ro/search/label/Tov\%C3\%A1bb[-] $\mathrm{k} \% \mathrm{C} 3 \% \mathrm{~A} 9 \mathrm{pz} \% \mathrm{C} 5 \% 91 \mathrm{k}$ [2015. november 10.]

${ }^{23}$ A Magyar Könyvtárosok IV. Szakmai Találkozójának programja (Budapest, 1996. augusztus 7-10). Forrás: http://vilagtalalkozo.oszk.hu/talalkozo_1996 [2016. június 13.]

${ }^{24}$ PORÁCZKY Rozália: A kolozsvári Lucian Blaga Egyetemi Könyvtár 1990-2000 között. [Elhangzott 2000-ben, Budapesten a Magyar Könyvtárosok V. Világtalálkozóján]. Forrás: http://vilagtalalkozo.oszk.hu/sites/vilagtalalkozo.oszk.hu/files/dok154.pdf [2016. június 13.]

${ }^{25}$ GURKA-BALLA Ilona: Helytörténeti kutatások megkönnyítése az interneten: mûhelytitkok adatbázisok összeállításáról. Forrás: http://vilagtalalkozo.oszk.hu/sites/vilagtalalkozo.oszk.[-] hu/files/dok124.pdf [2016. június 13.]

${ }^{26}$ BREM Ágnes - BODNÁR Robert: Kolozsvári Központi Egyetemi Könyvtár digitalizálási tevékenysége [előadás a Magyar Könyvtárosok VII. Világtalálkozóján, Budapest, 2013. Május 2829-én]. Forrás: http://vilagtalalkozo.oszk.hu/sites/vilagtalalkozo.oszk.hu/files/brem_agnes_[-] bognar_robert.pdf [2016. június 13.]

${ }^{27}$ Az RMKE körlevelén elérhető elektronikus hírlap; megrendelhető a lapszerkesztő e-mailcímén, jelenleg: bakai.magdolna@gmail.com. 


\section{GURKA-BALLA ILONA}

${ }^{28}$ A kolozsvári BBTE Könyvtár- és információtudomány szak magyar nyelvű honlapja. Forrás: http://kmti.hiphi.ubbcluj.ro [2016. június 13.]

${ }^{29}$ A kolozsvári BBTE Könyvtár- és információtudomány szak Facebook-oldala. Forrás: https:/ [-] www.facebook.com/BBTE-K\%C3\%B6nyvt $\%$ C3\%A1r-\%C3\%A9s-inform $\% \mathrm{C} 3 \% \mathrm{~A} 1[-]$ ci $\%$ C3\%B3tudom\%C3\%A1 ny-szak-245530092313812 [2015. november 10.]

${ }^{30}$ A Szabadság címú napilap cikkanyagának feldolgozásával Kolozsvár helytörténeti bibliográfiai eszköztárához járultak hozzá; más települések helytörténetéhez is készítettek szakbibliográfiákat a helyi sajtótermékek feldolgozásával (Tordaszentlászló, Ördöngösfüzes, Érmihályfalva, Nagyszalonta, Csíkszereda, Kézdivásárhely és környéke).

${ }^{31}$ Repertóriumot készítettek az Ellenzék című kolozsvári lap cikkanyagáról, a Keresztyén Szó hiányzó részeiről, két könyvtáros szaklapról.

32 A kolozsvári egyetemi könyvtár hálózati könyvtár, azaz 34 fiókintézmény és tanszéki könyvtár tartozik hozzá. Forrás: http://www.bcucluj.ro/filiale/filiale.php [2016. június 13.]

33 PORÁCZKY Rozália: A kolozsvári Lucian Blaga Egyetemi Könyvtár 1990-2000 között. Forrás: http://vilagtalalkozo.oszk.hu/sites/vilagtalalkozo.oszk.hu/files/dok154.pdf [2016. június 13.]

${ }^{34}$ KRISTÓF György: Az egyetem hivatása. Kolozsvár, Nagy Jenő könyvnyomdája, 1944. (Egyetem és egyetemi munka: előadások a kolozsvári m. kir. Ferenc József Tudományegyetem összes hallgatói számára) 13-14. p.

35 2008-tól kezdték a meglévô katalógusokat digitalizálni. Az első hagyományos katalógus 454063 katalóguskártyáját 395 html oldalon 9589 pdf-ben rögzítettek, 1 pdf lap 50 katalóguskártyát tartalmaz.

362016 júniusában már 675900 bibliográfiai rekordot tartalmaz az online katalógus, az új és a retrospektív anyagot együtt.

${ }^{37}$ A kolozsvári Központi Egyetemi Könyvtár honlapja. Forrás: http://bcucluj.ro [2016. június 20.]

Gurka-Balla Ilona 1990 óta könyvtáros a kolozsvári Lucian Blaga Központi Egyetemi Könyvtárban. Doktori dolgozatának megvédése (1996) után, 1999-től a Babes-Bolyai Tudományegyetemen tanársegéd, s a Történelem és Filozófia Kar keretén belül a könyvtár- és információtudomány szakirány tudományos irányítója. 